\title{
SEARCH OF PROTEIN KINASE CK2 INHIBITORS BASED ON PURINE-2,6-DIONES DERIVATIVES
}

\author{
M. V. PROTOPOPOV 1 , O. V. OSTRYNSKA ${ }^{2}$, D. H. IVANCHENKO ${ }^{3}$, S. A. STAROSYLA ${ }^{2}$, \\ V. G. BDZHOLA2, M. I. ROMANENKO ${ }^{3}$, S. M. YARMOLUK ${ }^{2}$ \\ ${ }^{1}$ Taras Shevchenko National University of Kyiv, Ukraine; \\ e-mail:mykola.protopopov@gmail.com; \\ ${ }^{2}$ Institute of Molecular Biology and Genetics, National Academy \\ of Sciences of Ukraine, Kyiv; \\ e-mail: sergiy@yarmoluk.org.ua; \\ ${ }^{3}$ Zaporozhye State Medical University, Ukraine; \\ e-mail: ivanchenko230181@gmail.com
}

This work is aimed to the search of protein kinase CK2 inhibitors among the purine-2,6-dione derivatives by molecular docking and biochemical tests. It was found that the most active compound 8-[2-[(3-methoxyphenyl)methylidene]hydrazine-1-yl]-3-methyl-7-(3-phenoxypropyl)-2,3,6,7-tetrahydro-1H-purine-2,6dione inhibited protein kinase $C K 2$ with $I_{50}$ value of $8.5 \mu M$ in vitro in kinase assay. Biochemical tests and computer simulation results allowed determining the binding mode of the most active compound and structure-activity relationships.

Ke y words: protein kinase CK2, inhibitor, purine-2,6-dione, xanthine, virtual screening.

$\mathrm{P}$ rotein kinases is a family of enzymes that catalyze the phosphorylation of proteins. Since the regulation of most physiological and pathological functions depends on the level of the protein substrate phosphorylation, protein kinases are key targets for the drugs development [1].

Casein kinase II (CK2) is a pleiotropic (has more than 500 protein substrates [2]), serine-threonine protein kinase. This enzyme uses both ATP and GTP molecules as a phosphate donor and can be able to phosphorylate the tyrosine residue [4]. This enzyme has a tetrameric structure and consists of two catalytic ( $\alpha, \alpha$ and/or $\alpha$ ') and two regulatory ( $\beta$ ) subunits [3]. Catalytic subunits are encoded by genes that are localized in different chromosomes $[5,6]$. It has been shown that high expression of $\alpha$ subunit causes suppression of apoptosis [7].

Protein kinase CK2 is involved in the development of a wide range of diseases. Viruses use this enzyme as a phosphorylating agent for their own proteins [8]. Inflammatory reactions are regulated by a number of transcription factors [9] activated by CK2. Overexpression or increased activity of this enzyme is observed in malignant neoplasms: lung cancer, hepatocellular cancer, colorectal cancer, breast cancer, leukemia, prostate cancer and other $[10,11]$. It has been shown that CK2 is involved in the development of neurodegenerative diseases [12]: Alzheimer's disease [13], Parkinson's disease $[14,15]$, schizophrenia [16], Guam-Parkinson's dementia, progressive supranuclear palsy and Pick's disease [15]. Recently, the involvement of protein kinase CK2 in angiogenesis-related diseases was established [17]. Since some protein fibers are substrates for CK2 (transcription factors, troponin, myosin light chain and skeletal muscle proteins), it is obvious that this protein kinase may be involved in the development of diseases affecting skeletal muscles, bone and muscle tissues [18].

Due to the fact that protein kinase CK2 is involved in the regulation of a significant number of metabolic and pathological processes, the search for new inhibitors is promising both for pharmaceutical use and for application as a research tool in molecular biology.

(C) 2017 Protopopov M. V. et al. This is an open-access article distributed under the terms of the Creative Commons Attribution License, which permits unrestricted use, distribution, and reproduction in any medium, provided the original author and source are credited. 
Derivatives of purine-2,6-dione (xanthine) are purine alkaloids. Some of the xanthines are widely used in medicine [19]. For example, sodium caffeine benzoate and eufilin are used as stimulants of the central nervous system, cardiotonics and for spasm of blood vessels. Theobromine and theophylline are spasmolytic (vasoconstrictor, bronchodilator) and diuretic agents. Diprophylline and xanthine nicotinate are used to improve peripheral and cerebral circulation, respectively. Pentoxifylline is used for treatment of disorders of peripheral circulation, atherosclerotic disorders, ischemic states after a heart attack, in ophthalmology and hearing disorders.

It is known that purine-2,6-dione derivatives are inhibitors of BRAF protein kinase [20], Caf1 human poly (A) selective ribonuclease [21], 5-HT1A receptor [22], adenosine receptor [23], adenosine A2B receptor [24] and HM74A receptor [25]. Therefore, we decided to search for CK2 inhibitors among xanthine derivatives.

\section{Materials and Methods}

The synthesis of compounds was carried out at the Department of Biological Chemistry of Zaporozhye State Medical University under the leadership of Dr. Pharm. Professor M. I. Romanenko. Molecular docking. In order to find CK2 inhibitors we have performed virtual screening of 1943 organic compounds using AutoDock 4.2.6 program targeting ATP-binding site of enzyme. Ligands for the docking were prepared with Vega ZZ (command line) [27] and MGL Tools 1.5.6 [26]. Calculations of ligand geometry were performed using AUTODOCK force field.

Docking was carried out in catalytic subunit of CK2. The crystal structure of human protein kinase CK2 was obtained from the Brookhaven Protein Data Bank (PDB ID: 3NSZ) [28].

Water molecules, ions, and ligand were removed from the PDB file of receptor.

Ligands were prepared by Vega ZZ (command line) and MGL Tools 1.5.6. The incoming formats of receptor and ligands data were converted into PDBQT-format with Vega ZZ in AUTODOCK force field to carry out calculation with the aid of Autodock program. This format contains the coordinates of the atoms and partial charges. Hydrogen atoms were removed from nonpolar atoms. The receptor was prepared using MGL Tools and AutoGrid.

For docking calculation, we have used parameters that reported earlier [29].
Visual analysis of the best-scored complexes was performed using Discovery Studio Visualizer 4.0 [30].

Biochemical testing. Compounds were tested using in vitro kinase assay [31]. Each test was done in triplicate in a reaction volume of $30 \mu \mathrm{l}$, containing $6 \mu \mathrm{g}$ of peptide substrate RRRDDDSDDD (New England Biolabs); 10 units of recombinant human CK2 holoenzyme (New England Biolabs); $50 \mu \mathrm{M}$ ATP and $\gamma$-labeled 32P ATP, diluted to specific activity $100 \mu \mathrm{Ci} / \mu \mathrm{M}$; CK2 buffer $(20 \mathrm{mM}$ Tris- $\mathrm{HCl}$, $\mathrm{pH}$ 7.5; $50 \mathrm{mM} \mathrm{KCl} ; 10 \mathrm{mM} \mathrm{MgCl}_{2}$ ) and inhibitor in varying concentrations. Incubation time was $20 \mathrm{~min}$ at $30^{\circ} \mathrm{C}$. The reaction was stopped by adding an equal volume of $10 \%$ o-phosphoric acid and the reaction mixture was loaded onto $20-\mathrm{mm}$ discs of phosphocellulose paper (Whatman). Disks were washed three times with 1\% o-phosphoric acid solution, air-dried at room temperature, and counted by the Cherenkov method in a beta-counter (LKB). As negative control an equal volume of DMSO was added to the reaction mixture. Percent inhibition was calculated as ratio of substrate-incorporated radioactivity in the presence of inhibitor to the radioactivity incorporated in control reactions, i.e. in the absence of inhibitor. Serial dilutions of inhibitor stock solution were used to determine its $\mathrm{IC}_{50}$ concentration.

\section{Results and Discussion}

To identify candidate inhibitors of CK2 we have performed structure-based virtual screening using molecular docking calculations. The virtual screening was performed using ATP-binding site of enzyme as the target and the collection of 1943 purine-2,6-dione derivatives.

After docking calculations, the best-ranked molecules based on predicted binding energy, were visually inspected in the complexes with amino acid residues of CK2 ATP-binding site.

The selected compounds were used for investigation of their inhibitory activity toward CK2 in vitro using a direct radiometric method [31]. The residual activity of CK2 at $10 \mu \mathrm{M}$ compound concentration is presented in Table 1 (the chemical structures of compounds were drawn in the program MarvinSketch Chemaxon [32]).

Accordingly to the results of the biochemical assay, it was found that compound 1-8-[2-[(3-methyloxyphenyl) methylidene]hydrazine-1-yl]-3-methyl7-(3-phenoxypropyl)-2,3,6,7 -tetrahydro-1H-purine-2,6-dione (compound 1) was the most active 
Structure and inhibitory activity of purine-2,6-dione derivatives toward CK2

\begin{tabular}{|c|c|c|c|c|c|}
\hline \# & Structure & $\begin{array}{c}\text { Residual } \\
\text { activity } \\
\text { at } 10 \mu \mathrm{M}, \%\end{array}$ & \# & Structure & $\begin{array}{c}\text { Residual } \\
\text { activity } \\
\text { at } 10 \mu \mathrm{M}, \%\end{array}$ \\
\hline 1 & & $\begin{array}{c}22.34 \\
\left(\mathrm{IC}_{50}=8.5 \mu \mathrm{M}\right)\end{array}$ & 2 & & 59.48 \\
\hline 3 & & 60.49 & 4 & & 69.75 \\
\hline 5 & & 71.05 & 6 & & 78.67 \\
\hline 7 & & 78.75 & 8 & & 80.49 \\
\hline 9 & & 81 & 10 & & 81.9 \\
\hline
\end{tabular}


Ta ble. (Continuation)

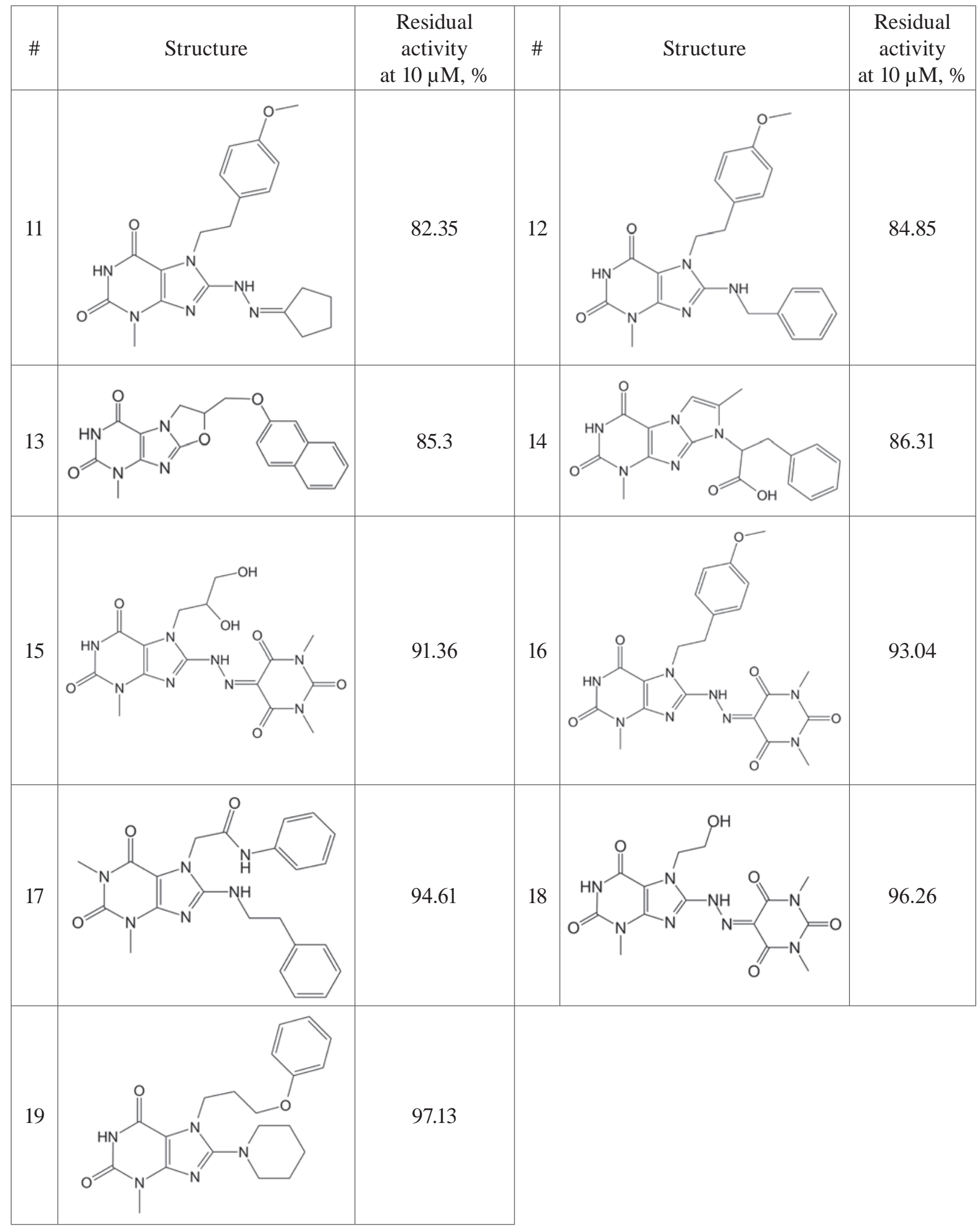


among the studied $\left(\mathrm{IC}_{50}=8.5 \mu \mathrm{M}\right)$. Complex of compound 1 with ATP-binding site CK2 was obtained using the program Autodock 4.2.6 (Figure).

The xanthine fragment of compound $\mathbf{1}$ is located in the adenine-binding site of the CK2 ATPbinding pocket and forms hydrogen bonds with Glu114 and Val116. Xanthine heterocycle is involved in hydrophobic $\pi$-alkyl interactions with Ile174 and Val66. Methyl in the third position is directed to the hydrophobic region II. 3-phenoxypropyl is oriented towards the active site and forms hydrogen bond with Lys68.

The substitution of hydrogen atom with benzyl or 4-methylbenzyl in the first position of compounds 3 and $\mathbf{9}$, respectively, leads to the loss of inhibitory activity toward CK2. It can be explained by displacement of xanthine cycle from the adenine-binding site with the loss of hydrogen bonds with the amino acid residues Glu114 and Val116.
Substituents containing flexible linkers in the seventh position of compounds $2,4,7,8,10,15,19$, 11, 12 lead to deterioration of stability of hydrogen bond with Lys68 and as a consequence to decrease of CK2 inhibitory activity.

Since the search of new inhibitors was conducted with the aim of further development of drugs on their basis, it is important to take into account the physico-chemical properties of the studied compounds. One of these parameters is LogP. Under Lipinski's rule of five $\log \mathrm{P}$ value must not exceed 5 . For compound $\mathbf{1}$ the value of cLogP was 2.9. Often, in order to improve the activity of compounds (especially in relation to protein kinase CK2), additional hydrophobic substituents are required. The inhibitory activity of compound $\mathbf{1}$ can be greatly improved by this approach.

As a result of our work we found a number of inhibitors of protein kinase CK2 among deriva-

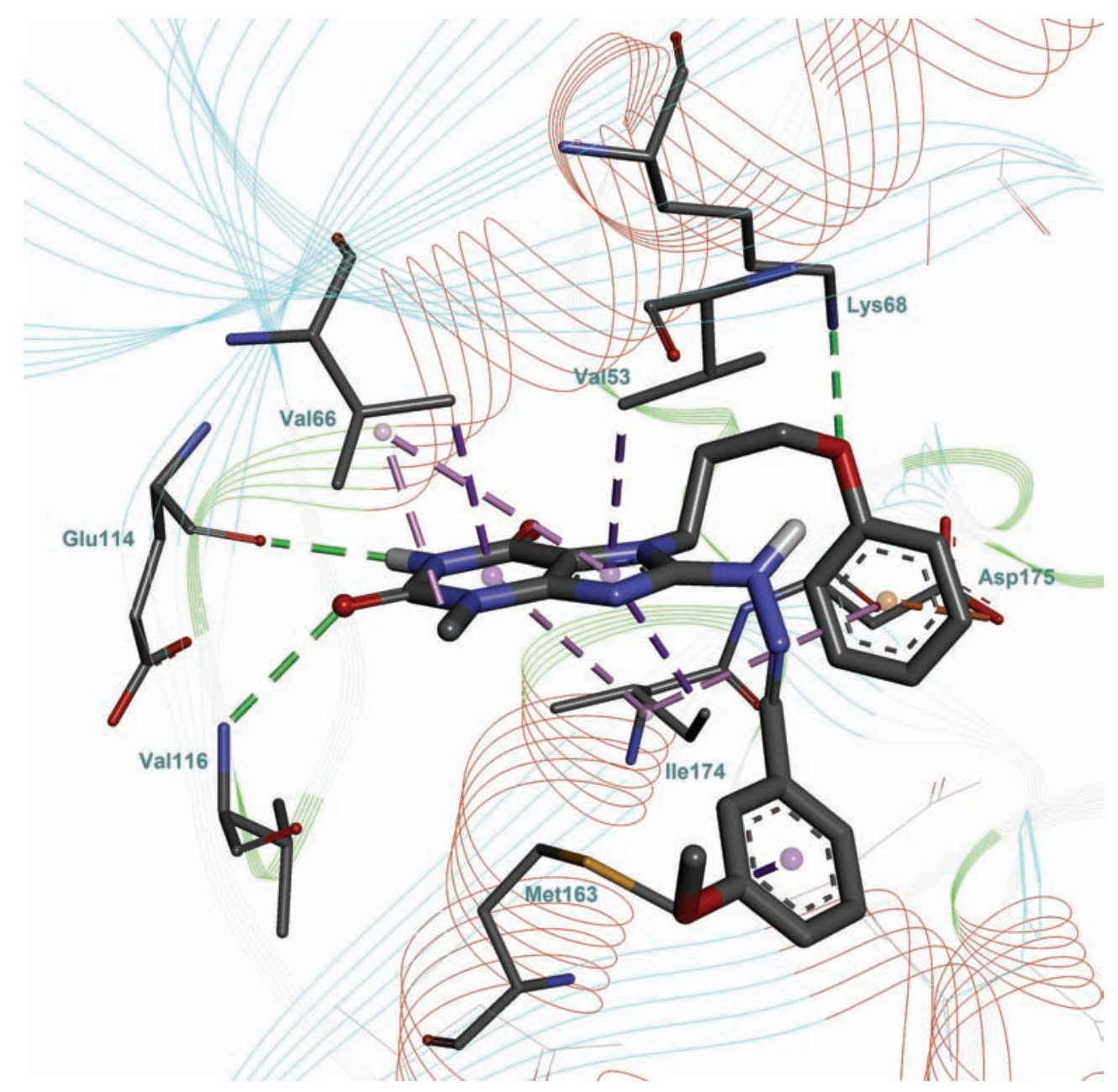

The complex of compound 1 with ATP-binding site of human protein kinase CK2. Hydrogen bonds are indicated by green dotted lines, hydrophobic bonds - by purple dotted lines 
tives of purine-2,6-dione. $\mathrm{IC}_{50}$ of the most active compound 8-[2-[(3-methoxyphenyl)methylidene] hydrazine-1-yl]-3-methyl-7-(3-phenoxypropyl)2,3,6,7-tetrahydro-1H-purine-2,6-dione is $8.5 \mu \mathrm{M}$. Summarizing analysis of SAR of the purine-2,6dione derivatives, the importance of the substituents in the first and seventh position should be emphasized. The substitution of hydrogen atom in the first position with other substitutions and in the seventh position on large flexible substitutions has a negative effect on the inhibitory activity of the compounds toward CK2.

\section{ПОШУК ІНГІБІТОРІВ ПРОТЕЇНКІНАЗИ СК2 СЕРЕД ПОХІДНИХ ПУРИН-2,6-ДІОНУ}

\section{М. В. Протопопов 1 , О. В. Остринська ${ }^{2}$, Д. Г. Іванченко ${ }^{3}$ С. А. Старосила ${ }^{2}$, В. Г. Бджола ${ }^{2}$, М. І. Романенко С. М. Ярмолюк ${ }^{2}$}

${ }^{1}$ Київський національний університет імені Тараса Шевченка, Україна; e-mail: mykola.protopopov@gmail.com; 2Інститут молекулярної біології та генетики НАН України, Київ; e-mail: sergiy@yarmoluk.org.ua;

ЗЗапорізький державний медичний університет; e-mail: ivanchenko230181@gmail.com

Робота присвячена пошуку інгібіторів протеїнкінази СК2 серед похідних пурин-2,6діону за допомогою молекулярного докінгу та біохімічного тестування. Встановлено, що 8-[2-[(3-метилоксифеніл)метиліден] гідразин-1-іл]-3-метил-7-(3-феноксипропіл)2,3,6,7-тетрагідро-1Н-пурин-2,6-діон інгібував активність протеїнкінази СК2 з $\mathrm{IC}_{50} 8,5$ мкM. Під час порівняння результатів біохімічного тестування та комп'ютерного моделювання визначено залежність інгібувальної активності сполук від їхньої структури та встановлено положення лігандів у сайті зв’язування.

К л юч в в с ло в а: інгібітори протеїнкінази СК2, ксантин, пурин-2,6-діон, віртуальний скринінг.

\section{ПОИСК ИНГИБИТОРОВ ПРОТЕИНКИНАЗЫ СК2 СРЕДИ ПРОИЗВОДНЫХ ПУРИН-2,6-ДИОНА}

\author{
Н. В. Протопопов ${ }^{1}$ О. В. Остринская ${ }^{2}$, \\ Д. Г. Иванченко , С. А. Старосила ${ }^{2}$, \\ В. Г. Бджола ${ }^{2}$ Н. И. Романенко \\ С. Н. Ярмолюк ${ }^{2}$
}

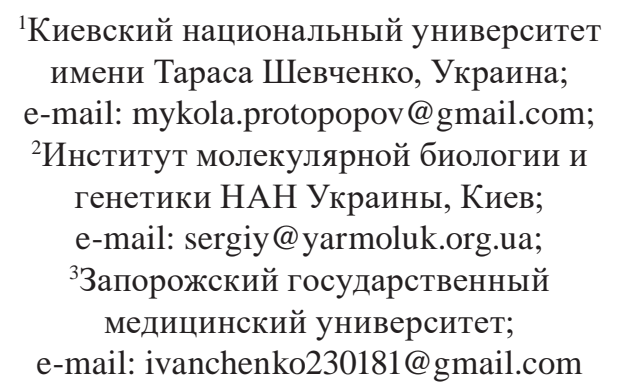

Работа посвящена поиску ингибиторов протеинкиназы СК2 среди производных пурин2,6-диона с помощью молекулярного докинга и биохимического тестирования. Установлено, что 8- [2 - [(3-метилоксифенил) метилиден] гидразин-1-ил]-3-метил-7-(3-феноксипропил)2,3,6,7-тетрагидро-1Н-пурин-2,6-дион ингибировал активность протеинкиназы СК2 с $\mathrm{IC}_{50}$ 8,5 мкм. При сопоставлении результатов биохимического тестирования и компьютерного моделирования определена зависимость ингибиторной активности соединений от их структуры и установлено расположение лигандов в сайте связывания.

К лючев ы е с лов а: ингибиторы протеинкиназы СК2, ксантин, пурин-2,6-дион, виртуальный скрининг.

\section{References}

1. Cohen P. Protein kinases - the major drug targets of the twenty-first century? Nat Rev Drug Discov. 2002; 1(4): 309-315.

2. Yarmoluk SM, Nyporko AYu, Bdzhola VG. Rational design of protein kinase inhibitors. Biopolym Cell. 2013; 29(4): 339-347.

3. Litchfield DW. Protein kinase CK2: structure, regulation and role in cellular decisions of life and death. Biochem J. 2003; 369(Pt 1): 1-15. 
4. Vilk G, Weber JE, Turowec JP, Duncan JS, Wu C, Derksen DR, Zien P, Sarno S, Donella-Deana A, Lajoie G, Pinna LA, Li SS, Litchfield DW. Protein kinase CK2 catalyzes tyrosine phosphorylation in mammalian cells. Cell Signal. 2008; 20(11): 1942-1951.

5. Wirkner U, Voss $\mathrm{H}$, Lichter $\mathrm{P}$, Ansorge W, Pyerin W. The human gene (CSNK2A1) coding for the casein kinase II subunit alpha is located on chromosome 20 and contains tandemly arranged Alu repeats. Genomics. 1994; 19(2): 257-265.

6. Yang-Feng TL, Naiman T, Kopatz I, Eli D, Dafni N, Canaani D. Assignment of the Human Casein Kinase II $\alpha^{\prime}$ Subunit Gene (CSNK2A1) to Chromosome 16p13.2-p13.3. Genomics. 1994; 19(1): 173.

7. Trembley JH, Chen Z, Unger G, Slaton J, Kren BT, Van Waes C, Ahmed K. Emergence of protein kinase CK2 as a key target in cancer therapy. Biofactors. 2010; 36(3): 187-195.

8. McElhinny JA, Trushin SA, Bren GD, Chester N, Paya CV. Casein kinase II phosphorylates I kappa B alpha at S-283, S-289, S-293, and T-291 and is required for its degradation. Mol Cell Biol. 1996; 16(3): 899-906.

9. Bird TA, Schooley K, Dower SK, Hagen H, Virca GD. Activation of nuclear transcription factor NF-kappaB by interleukin-1 is accompanied by casein kinase II-mediated phosphorylation of the p65 subunit. J Biol Chem. 1997; 272(51): 32606-32612.

10. Chua MM, Ortega CE, Sheikh A, Lee M, Abdul-Rassoul H, Hartshorn KL, Dominguez I. CK2 in Cancer: Cellular and Biochemical Mechanisms and Potential Therapeutic Target. Pharmaceuticals (Basel). 2017; 10(1). pii: E18.

11. Gowda C, Song C, Kapadia M, Payne JL, $\mathrm{Hu}$ T, Ding Y, Dovat S. Regulation of cellular proliferation in acute lymphoblastic leukemia by Casein Kinase II (CK2) and Ikaros. Adv Biol Regul. 2017; 63: 71-80.

12. Perez DI, Gil C, Martinez A. Protein kinases CK1 and CK2 as new targets for neurodegenerative diseases. Med Res Rev. 2011; 31(6): 924-954.

13. Rosenberger AF, Morrema TH, Gerritsen WH, van Haastert ES, Snkhchyan H, Hilhorst R, Rozemuller AJ, Scheltens P, van der Vies SM, Hoozemans JJ. Increased occurrence of protein kinase CK2 in astrocytes in Alzheimer's disease pathology. J Neuroinflammation. 2016; 13: 4.
14. Rebholz H, Zhou M, Nairn AC, Greengard P, Flajolet M. Selective knockout of the casein kinase 2 in $\mathrm{d} 1$ medium spiny neurons controls dopaminergic function. Biol Psychiatry. 2013; 74(2): 113-121.

15. Ryu MY, Kim DW, Arima K, Mouradian MM, Kim SU, Lee G. Localization of CKII beta subunits in Lewy bodies of Parkinson's disease. J Neurol Sci. 2008; 266(1-2): 9-12.

16. Aksenova MV, Burbaeva GS, Kandror KV, Kapkov DV, Stepanov AS. The decreased level of casein kinase 2 in brain cortex of schizophrenic and Alzheimer's disease patients. FEBS Lett. 1991; 279(1): 55-57.

17. Ljubimov AV, Caballero S, Aoki AM, Pinna LA, Grant MB, Castellon R. Involvement of protein kinase CK2 in angiogenesis and retinal neovascularization. Invest Ophthalmol Vis Sci. 2004; 45(12): 4583-4591.

18. Meggio F, Pinna LA. One-thousand-and-one substrates of protein kinase CK2? FASEB J. 2003; 17(3): 349-368.

19. DrugBank database. Access mode: https://www. drugbank.ca/.

20. Luo C, Xie P, Marmorstein R. Identification of BRAF inhibitors through in silico screening. J Med Chem. 2008; 51(19): 6121-6127.

21. Jadhav GP, Kaur I, Maryati M, Airhihen B, Fischer PM, Winkler GS. Discovery, synthesis and biochemical profiling of purine-2,6-dione derivatives as inhibitors of the human poly(A)selective ribonuclease Caf1. Bioorg Med Chem Lett. 2015; 25(19): 4219-4224.

22. Chloń G, Pawłowski M, Duszyńska B, Szaro A, Tatarczńska E, Kłodzińska AL, Chojnacka-Wójcik E. Synthesis, 5-HT1A and 5-HT2A receptor activity of new 1-phenylpiperazinylpropyl derivatives with arylalkyl substituents in position 7 of purine2,6-dione. Pol J Pharmacol. 2001; 53(4): 359368.

23. Pat. 20120828, US8252797, Heterocyclic compounds as adenosine receptor antagonist / Palle V., Basu S., Waman Y., Ramdas V., Barawkar D., Patel M., Panmand A. Publ. 28.08.2012.

24. Pat. 20080226, US7335655, 8-Heteroaryl xanthine adenosine A2B receptor antagonists / Baraldi P., Pier P. Publ. 26.02.2008.

25. Pat. 20100715, US2010179128, Xanthine derivatives as selective $\mathrm{hm} 74 \mathrm{a}$ agonists / 
Hatley R., Heer J., Liddle J., Mcmurtrie M., Pinto I., Rahman S., Smith I. Publ. 15.07.2010.

26. Morris GM, Huey R, Lindstrom W, Sanner MF, Belew RK, Goodsell DS, Olson AJ. AutoDock4 and AutoDockTools4: Automated docking with selective receptor flexibility. J Comput Chem. 2009; 30(16): 2785-2791.

27. Pedretti A, Villa L, Vistoli G. VEGA - an open platform to develop chemo-bio-informatics applications, using plug-in architecture and script programming. J Comput Aided Mol Des. 2004; 18(3): 167-173.

28. Ferguson AD, Sheth PR, Basso AD, Paliwal S, Gray K, Fischmann TO, Le HV. Structural basis of CX-4945 binding to human protein kinase CK2. FEBS Lett. 2011; 585(1): 104-110.
29. Syniugin AR, Ostrynska OV, Chekanov MO, Volynets GP, Starosyla SA, Bdzhola VG, Yarmoluk SM. Design, synthesis and evaluation of 3-quinoline carboxylic acids as new inhibitors of protein kinase CK2. J Enzyme Inhib Med Chem. 2016; 31(sup4): 160-169.

30. Discovery Studio Visualizer. Access mode: http://accelrys.com/.

31. Hastie CJ, McLauchlan HJ, Cohen P. Assay of protein kinases using radiolabeled ATP: a protocol. Nat Protoc. 2006; 1(2): 968-971.

32. Marvin was used for drawing, displaying and characterizing chemical structures, substructures and reactions, Marvin 17.11.0, 2017, ChemAxon (http://www.chemaxon.com).

Received 30.06.2017 